\title{
CHANGING PARADIGMS IN SOUTHEAST ASIAN ARCHAEOLOGY
}

\author{
Joyce C. White \\ Institute for Southeast Asian Archaeology and University of Pennsylvania Museum
}

\begin{abstract}
In order for Southeast Asian archaeologists to effectively engage with global archaeological discussions of the $21^{\text {st }}$ century, adoption of new paradigms is advocated. The prevalent mid-twentieth century paradigm's reliance on essentialized frameworks and directional macro-views should be replaced with a forward-facing, "emergent" paradigm and an emphasis on community-scale analyses in alignment with current trends in archaeological theory. An example contrasting the early i\&i pottery with early copper-base metallurgy in Thailand illustrates how this new perspective could approach prehistoric data.
\end{abstract}

\section{INTRODUCTION}

When scholars reach the point in their careers that they are asked to contribute keynote addresses ${ }^{1}$, such occasions invite reflection on 'the state of the discipline' and on possible paths forward. As 20th century scholarship recedes into historical background and $21^{\text {st }}$ century scholarship finds its footing, it seems appropriate to ask: Where is the discipline of Southeast Asian prehistoric archaeology going? Moreover, what should Southeast Asian archaeologists prioritize as we go forward in this century? Of course, there are many priorities.

There remain huge temporal and geographic gaps in the basic data that will take decades of research to fill in; that is, if we get there before the looters and developers decimate the archaeological evidence (e.g., Lewis et al. 2015). There are exciting fieldwork methodologies, such as LiDAR (Hanus and Evans 2015) and ground penetrating radar (Duke et al. 2016) that are beginning to enable richer and more rapid assessment of our sites, which should improve the efficiency and quality of field data acquisition. Expanded development and application is needed of postexcavation methodologies, including applications of archaeometric techniques (e.g., Carter and Dussubieux 2016; King et al. 2015: Pryce et al. 2014). There is a backlog of legacy work that needs to be published, and Ban Chiang is only one of many insufficiently published excavations

\footnotetext{
${ }^{1}$ An earlier version of this text was prepared for a keynote address at the European Association of Southeast Asian Archaeologists (EurASEAA), $14^{\text {th }}$ International Conference that took place in Dublin, September 18-21 2012.
}

(e.g., Tha Kae, Ban Mai Chaimongkol, Non Pa Wai, and many other sites in central Thailand; but see White and Hamilton [in press] for progress on Ban Chiang).

But what I want to focus on here is our paradigmatic frameworks. Paradigms - that set of assumptions, concepts, values, and practices that underlie an intellectual discipline at particular points in time - matter. They matter partly because if we are parroting an out-of-date archaeological agenda, we will miss out on three important things crucial for the vitality of the discipline of Southeast Asian archaeology in the long term. First is institutional support in terms of jobs. Second is resources. In both cases, applicants for jobs and grants need to be in tune with scholarly trends. Third, what interests me most in this paper, is our place in global archaeological discussions. Participating in global archaeological conversations, being a player in tune with the currents of the time, tends to assist in gaining institutional support and resources.

I would like to note especially for the younger generation that change in archaeological thinking is inevitable. It is not something to be rejected or feared. There will be things one learns in graduate school from one's professors as gospel, and 20,30 years later (sometimes in only a year or two) one discovers those ideas were wrong. There will be ideas one once rejected only later to find oneself agreeing with the idea previously dismissed.

As an example from my own experience, when I went through graduate school in the late 1970s, it was gospel that prehistoric sites in Thailand with lots of burials were cemeteries. If there were occupation materials around the burials, these came from preceding and unrelated older occupations into which the cemeteries were dug. One graduate student at the University of Michigan a few years ahead of me, Bill McDonald, proposed a different idea - that burials at Ban Kao and Non Nok Tha were interred in residential areas (MacDonald 1980a, 1980b). I recall that I along with my peers dutifully parroted our seniors and poo-pooed that idea. Years later, in the course of working with Ban Chiang data, I found I could not make the Ban Chiang burial evidence fit a cemetery taphonomic model. With a bit of chagrin, I slowly came to the same conclusion as Bill McDonald, only a few decades later. I now believe that 
most of the purported prehistoric "cemeteries" in Thailand were actually burials interred under and around houses in ongoing occupations, a practice termed "residential burial" (Adams and King 2011). This taphonomic re-interpretation could significantly change how we interpret metal age societies (e.g., White and Eyre 2011). Odds are that a lot of archaeological truths of the past few decades will be proven inaccurate, and the coming generation of Southeast Asian archaeologists will be the ones proving it! Then of course, the cycle will repeat and soon the next generation of students will be disproving the current generation's pet theories. This is the way of scholarship as we strive to find truth in an ongoing discourse as new data and ideas are integrated with previous understandings.

In my view, Southeast Asian prehistoric archaeology is at a juncture of major change in paradigmatic frameworks. Here, I am speaking mainly about mainland Southeast Asian archaeology (MSEA) although the topic is also pertinent to island Southeast Asia. To begin this discussion, we need to start by asking, what is the prevalent Southeast Asian archaeological paradigm? I think most regional archaeologists will agree that most literature from the last four decades for MSEA reflects the following:

- heavy investment in the Three Age System (Neolithic, Bronze Age, Iron Age)

- neo-/cultural evolutionary focus privileging origins of states issues

- "progressive/complexity" narratives

- core/periphery/world systems interregional assumptions

I think it is fair to term this the "Mid-20th Century Anglophone Paradigm," a paradigm which privileges macroviews.

\section{ISSUES OF SCALE AND THE 'GRAND NARRATIVE'}

From a bird's eye view, one can tell a Southeast Asian prehistory story from a Mid-20th Century Anglophone Paradigm. But up close, the data do not work well from this narrative. It is like telling the story of human evolution ignoring genetics, selection, and adaptation, and only looking at selected fossil evidence. As we all know, the shelf life of that simple linear story of hominid evolution has expired.

In addition to the distortions of a bird's eye view on archaeological data are distortions from a rear-view mirror perspective on the past. We can see this in the many publications whose titles include the words "Origins of..." origins of agriculture, origins of metallurgy, origins of the state, origins of the bronze age... This rear-view mirror perspective encourages archaeologists to take a number of intellectual short cuts that:

- conflate processes - for example, equate transmission of the technology of bronze production to the development of hierarchical "Bronze Age" societies. Most scholars of early metallurgy now recognize the need to disentangle the technological from the social processes (Thornton and Roberts 2014).

- downplay variability - such as when we conjure up a normative picture from a diverse dataset. When we hold up a site, for example, as exemplative for a time period when in its synchronic context it turns out to be atypical or one of many variations (e.g., Ban Non Wat as exemplative for the "Bronze Age"; Higham 2015).

- ignore data - that do not fit the prevalent norm and stereotyped trajectory. For example, ignoring evidence for, and implications of, millet cultivation in reconstructing early agricultural systems in our region because of an over-focus on rice (see Weber et al. 2010 for discussion of millet).

- gloss over evidence - by giving a summary qualitative assessment without quantitative back-up and skipping the details that may not support our interpretation. For example, asserting that a wide-spread decorative ceramic style testified to population expansion, glossing over the lack of palaeodemographic, technological, and other evidence supporting said expansion (cf., Fix 2011; King et al. 2015).

When we generalize from the macroview with its inbuilt directionality onto what we then assume must be going on at the microlevel, we are missing or dismissing salient phenomena of the past. Imagine if we were biological scientists, we could never get away with a paradigm of change with built-in directionality, unless perhaps we were of a creationist persuasion. So why do we do it?

One of the great attractions of the Bird's Eye View/Rear View Mirror paradigm is that it generates lots of maps with big sweeping arrows. It is great fun, and we all do it - I do it - like when a colleague you have not seen in five years comes to town, and you go out to dinner, and before the entrées have arrived, your napkins are covered with crude sketches of Asia, big arrows, and dates, as you chew the fat over the latest archaeological, linguistic, and other data. But we need to remember that although grand narratives are tantalizing, the big arrow schemes are models that need ground-truthing, especially today in Southeast Asia. Despite persistent statements written with tones of finality (e.g., Bellwood 2011; Higham 2015), the evidence is not unanimous that any particular scheme has been proven. Indeed, there are so many gaps in our data that we can connect the dots in any number of ways.

Whenever I am peeved by this or that big arrow discussion, I take great comfort in reading linguistic discussions. Linguists are not unanimous about anything. Not only does each linguist seem to have a different map, each linguist seems to have a different map for each publication. We archaeologists could learn something from the linguists, and from the geneticists, who also generate new maps with alarming frequency. Alternative scenarios are stimulating for the discipline. The point is, the big arrow maps are testable models and we need to start focusing more on the tests, as we have plenty of arrows that need evidence-based research. Everyone, the linguists, the geneticists, and we archaeologists, lament the paucity of hard archaeological data and research in our region. This is a challenge for the future of our discipline.

If Southeast Asian archaeology is to make progress from here on, our efforts need to focus on microscale social 
processes, processes analogous to studying mutation, selection, and other genetic mechanisms at the community, population, and landscape scales. To do this we need to focus more on our own data. Take one key process, such as selection, which operates on the options that are available. If we are going to understand why something was selected and incorporated into a past social system, like bronze technology, we need to know and assess the alternatives. Selection can favor variants with outcomes that may differ from our preconceived ideas of what is advantageous. Selection may favor, for example, bronze production processes that by our $21^{\text {st }}$ century measures appear inefficient, but which may have taken the least total effort to attain the desired product given the labor management and consumer systems. Another process more "efficient" from a modern value system could have extracted more metal product per volume of ore albeit with much greater labor input not consistent with the labor economy. When we consider "efficient for whom or for what aspect of the process," selection three thousand years ago may have weighted options with values far different from our own. It may have favored stone adzes for workhorse tools, while the more 'technologically advanced' bronze adzes might have been valued more as exchange valuables than as mechanically efficient implements. Early adoption of bronze technology may not have even been considered desirable or advantageous among some communities for any number of reasons ranging from costs to cultural values, even if the technology was available in the region. Thus, assessing variability of different kinds (value systems, implement types, contexts of recovery) and scales (household, village, region) is one key to understanding past change.

We need to appreciate that models, such as the farming/language dispersal model, are usually reliant on a lot of untested assumptions. Periodically an assumption gets knocked out with new data or a new interpretation, and when enough cracks in the façade of the seemingly invincible model accumulate, quite suddenly the whole set of relationships collapses. A recent example can be seen in island Southeast Asia, where Mathew Spriggs' (2011) Antiquity article notes that the collapse of consensus among linguists for Blust's phylogenetic model of Austronesian languages liberated archaeologists to reexamine their data and rethink many aspects of the farming/language dispersal hypothesis of neolithic expansion (e.g., see Donohue and Denham 2010). It is a good lesson for archaeologists working on the mainland not to make the data and interpretations from an ancillary discipline the linchpin holding up our models, because those linchpins can collapse at any moment. We need to be actively assessing our own data on their own terms.

Austroasiatic (AA) languages likewise are being rethought. Articles in the meaty volume Dynamics of Human Diversity: The Case of Mainland Southeast Asia (Enfield 2011) discuss possible locations for the homeland for proto-Austroasiatic speaking people and it was not the Yangtze. There was agreement that the AA homeland must fall in the zone from Assam in northeastern India/Bay of Bengal area through Burma, Laos, and Thailand. One of the new big arrow maps proposed by Sidwell and Blench (2011: 337) suggests that the AA homeland was in the middle Mekong. Expansion may have been more southeast to northwest in direction. Other linguists have suggested a more western homeland, even near the Bay of Bengal with subsequent expansion toward the east (e.g., Donegan and Stamp 2004). How these linguistic models can be reconciled with currently prevalent archaeological models for the appearance and spread of rice farming in mainland Southeast Asia from northeast to southwest in a "Neolithic wave of advance" (e.g., Higham et al. 2011:541; see also Bellwood 2011) will be challenging for proponents of the farming/language dispersal model. Maybe those models will need some reconsideration. There seems to be some disagreement among the linguists about whether or not rice-related vocabulary can be traced back to proto-Austroasiatic. Taro seems to have a deeper source than rice, being traceable according to Blench (2011) to 12 of 13 AA branches, with the word for rice only found in 7 branches. Archaeologists have yet to consider how a root crop - taro - would impact their models for dispersal of the "neolithic," which currently are reliant on cereal cultivation, especially of rice, as the driver of population expansion (e.g., Bellwood 2011; Bell wood et al. 2013; Higham 2002; Higham et al. 2011).

\section{THE THREE AGE SYSTEM AND SOUTHEAST ASIAN ARCHAEOLOGY}

On the topic of the "neolithic," Southeast Asian archaeologists need to be honest about the pitfalls of Three Age nomenclature, and stop mindlessly falling into these by essentializing the terminology. To essentialize is a logical fallacy whereby an abstract concept is treated as if it is a concrete reality with essential, inherent properties (Liebmann 2008). For example, archaeologists essentialize when they assert that an abstract concept, such as "the bronze age," has the inherent essential property of social stratification. This logical argument can have a structure something like this: Society A has bronze technology (but no iron technology). Therefore, Society A is Bronze Age. An essential property of the Bronze Age is social stratification; therefore, Society A has social stratification. This type of false argument is also called the fallacy of reification. The fallacious logic may be bolstered by other lines of false logic, such as the fallacy of over-generalizing from small samples. When we essentialize the bronze age, e.g., by asserting that Southeast Asia has a "Bronze Age" comparable to that of Mesopotamia or central plains China (e.g., Higham 1996:320; Higham and Thosarat 2012:22), we come across as willfully unobservant. Such disingenuous comparisons marginalize our region, and we would serve our field better by exploring and articulating an authentic understanding of the social place of bronze technology in the context of Southeast Asia (e.g., see discussions in White and Hamilton 2009 in press; White and Pigott 1996).

As another example of the slipperiness of Three Age nomenclature, I refer again to Spriggs' Antiquity article, in which he makes a statement that would be sacrilegious in 
some circles and certainly goes against what I was taught in graduate school, namely that the "process of 'Neolithisation' did not necessarily involve agriculture at all" (Spriggs 2011: 523)! I believe Vietnamese archaeologists will happily concur with Spriggs (e.g., Nguyen Khai $\mathrm{Su}$ et al. 2004). He goes on to state (Spriggs 2011: 523) that it did involve "...pottery, its complex vessel forms and surface finish surely betokening new social relations; it certainly did involve a suite of shell artefacts with equally novel meanings, and also new technologies of cloth and barkcloth. Julian Thomas (1997: 59) has put it succinctly: 'material things did not attend the Neolithic, they were the $\mathrm{Ne}$ olithic'". Whether or not we agree with this last statement, it at least illustrates the trend to reexamine Three Age terminology and disentangle assumptions that particular processes, such as pottery production and agriculture, necessarily co-occurred.

My larger point is, in the end, we need our nomenclature to serve us; we should not be serving a nomenclature that has become wedded to outdated conceptual frameworks, such as a normative view of the neolithic or bronze age. Three Age terminology means different things to different scholars in different regions. As many readers know, in my own view, Southeast Asia needs to demote the role and prominence of Three Age nomenclature in our models. At least we should lowercase it and unhinge the terms and concepts from the rigid criteria and unfounded assumptions of accompanying sociopolitical correlates (White 2002; see White and Hamilton in press for extended discussion). We need to assess the archaeological evidence on its own terms in its full variety without being beholden to the models and vocabulary of the past. The Three Age System was a useful framework in the nineteenth century and well into the twentieth, but in the twenty-first century in Southeast Asia, it is outmoded as anything more than a techno-chronological frame.

\section{CHANGING PERSPECTIVES AND COMMON GROUND}

It is safe to say that archaeologists of any persuasion are interested in at least these two genres of questions, both related to social networks, or rather palaeo-social networks:

- How did prehistoric societies "work," and how and why did those workings change over time?

- Who was interacting with whom, and how were they doing it?

How can we get a fresh perspective on Southeast Asia's past, different from the outdated Mid-20 $0^{\text {th }}$ Century Anglophone Paradigm discussed above? How can we change from rear view to front view and regain the on-the-ground perspective of prehistoric peoples, moving toward a future that was not pre-ordained? I think this is, in essence, what many of the critiques of neoevolutionary perspectives as well as the resultant theoretical and methodological advances over the last thirty and more years have been doing (vide Hodder 2012). Practice theory and agency (e.g., Barrett 2012; Bourdieu 1977), human behavioral ecology and Darwinian archaeology (e.g., Bird and O'Connell 2012; Shennan 2012), anthropology of technology and behavioral archaeology (e.g., LaMotta 2012; Lemmonier 1986; Schiffer 2001), self-organization theory (e.g., Kohler 2012) - all of these approaches strive to bring choice, strategy, contingency, and diversity into our thinking about the past. In essence, these are perspectives that attempt to change the archaeological paradigm toward a forward-facing perspective, an "emergent" perspective (Fowler 2013; Hodder 2012:163; Kohler 2012). These frameworks are putting variability into discussions of temporal cultural change without assumed directionality, pacing, or prioritized outcomes. We, in Southeast Asian archaeology, are only just beginning to bring these perspectives to our data (e.g., Acabado 2014; Favereaux and Bellina 2016; Marwick 2008; White 2011). In my view, not only do the newer frameworks have much to give to us, but we have much to contribute to those perspectives and the associated conversations occurring at the global level. If we aggressively and astutely do this, Southeast Asia will have a much bigger place at the table of international archaeology, and could even be leaders in many of those conversations.

Engaging our data in these perspectives is not just a case of search and replace, for example, search for diffusion and replace it with transmission, and then think our manuscript is au courant. Much more drilling down will be needed. The key shift is to focus on smaller-scale phenomena and processes and build a structure from our data rather than trying to match our data to a pre-existing template or checklist, e.g., specialization check, hierarchy check, etc. Test the big arrows in the background by fore-grounding the nitty-gritty relationships evidenced in our data. To do this, there is a set of concepts and research priorities that can provide building blocks without getting bogged down in a lot of irritating jargon or taking sides in contentious contemporary theory debates:

- identify communities at various scales as the core units making decisions.

- assess variability, highlight it and position it rather than hide it. Selection in the evolutionary sense selects from options available; hence, change can only be explained in the context of variation (Bleed 1997).

- define social networks, as interaction flows introduce variation and underpin processes of selection.

- contextualize social networks among communities of various kinds and scales over the temporal dimension in order to provide a more dynamic, much meatier and plausible narrative, where the impact of specific variables (e.g., climate change, regional economic strategies) can be observed and their impact on social choices assessed without assuming that a society's 'Age' or stage will determine the path taken.

Implementing these concepts and procedures will enable our data to be assessed from "bottom-up" points of view. 


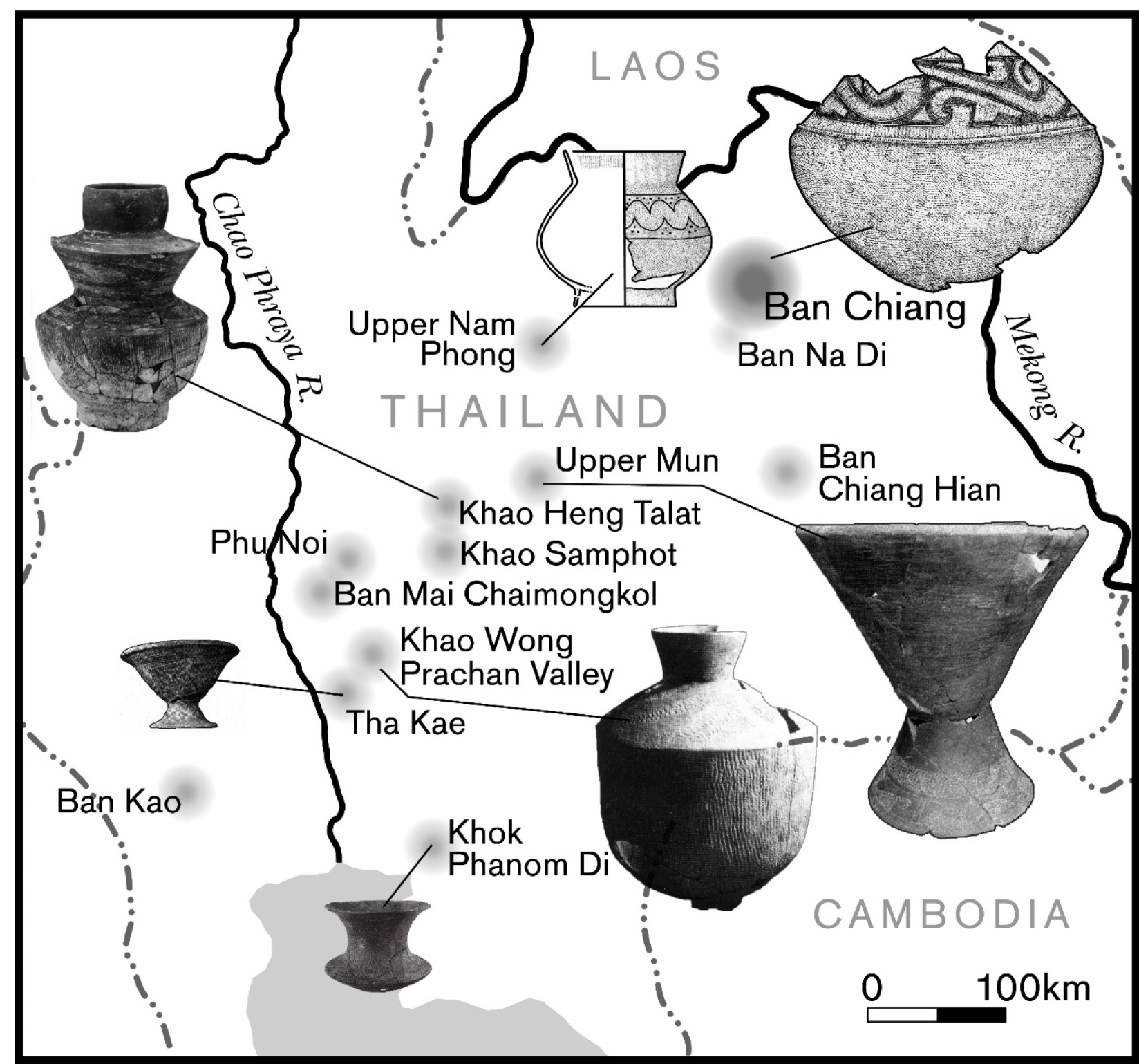

Figure 1. Map of Thailand illustrating variation in vessel form of i\&i pottery by ceramic subregion. Subregions continue to have distinct pottery in metal age phases.

\section{TECHNOLOGICAL COMMUNITIES}

\section{A pottery example}

To illustrate how this approach can work, we can take as a small example the so-called 'i\&i' pottery (incised and impressed; Rispoli 2007). Many will be familiar with the role this pottery plays in discussions of the farming/language dispersal hypothesis in mainland Southeast Asia, i.e., proponents assert that the dispersal of this decorative style marks the dispersal of farmers, especially of rice farmers, and the concurrent dispersal of Austroasiatic languages across mainland Southeast Asia (e.g., Higham 2002; Higham et al. 2011). Sherds of course do not farm or breed, nor do they speak languages, but they can provide a lot information about communities - communities of potters and pot consumers.
Looking at these pots from the potter's point of view, we might ask: what does the material evidence say about the communities doing the potting and what is actually moving? What are the networks? Is it the potters who bring their craft to new communities as they and farmers fission off during a process of rapid demic diffusion, as per the argument made by Petrequin and Petrequin (1999, cited by Spriggs 2011) for the Lapita? They argued that the manufacturing techniques, specialized forms and specific surface treatments and design systems of Lapita pottery, a suite of techniques requiring a long apprenticeship, indicate that potters making Lapita pottery must have migrated themselves from island Southeast Asia to the Bismarck Islands. Or was it just the decorative style moving, through borrowing a surface treatment by in situ communities of potters exposed to a style that consumers desired (e.g., the 
Zarmaganda, Gosselain 2008:172), with the potters staying put, i.e. localized non-moving communities of potters? Or were potters mobile but moving to extant villages independently of farmers or away from natal communities, as for example part of a marriage exchange system or an itinerant craftsperson production system (e.g., MacEachern 1998:123)? Or were the pots themselves moving, such as if they were being made in a few workshops, or at particular localities, and then the pots as commodities traded or exchanged widely, like the Tumleo of the Sepik coast, (Welsch and Terrell 1998:172)?

The i\&i pots themselves, if properly studied, should be able to shed light on these alternative scenarios regarding the communities of potters and their networks of interaction. I want to emphasize that at present, we do not have enough evidence to conclusively decide among these or other potential scenarios, but we can pose the question and ask what kinds of pertinent data exist so far, and what kinds of additional data we would need to address these questions.

Once we define a community or communities of interest - in this case, potters making i\&i pottery - and we have a variety of potential networking scenarios that could account for the horizon phenomenon in the archaeological record, a key question to ask is, what kinds of variability exist in the evidence of i\&i pottery that can shed light on the communities practicing its manufacture? If one looks at pottery with i\&i decoration from sites in Thailand, different subregions are seen to have strikingly distinct vessel forms (Figure 1; see also White and Eyre 2011). This "ceramic subregion" phenomenon appears to have been present during the pre-metal period and it continued through the metal ages.

Ideally at this point in our investigation we would evaluate variability in ceramic technology, namely, the various chaînes opératoires in evidence for i\&i pottery in each subregion (cf Jones 2002). But very little in-depth quality evidence exists for full chaînes opératoires for i\&i pottery. Recent ethnographic research among traditional potters (e.g., Gosselain 1998, 2008) has found that in a potterymaking sequence, the vessel primary forming or rough-out is the most conservative part of a vessel-manufacturing sequence; in other words, vessel-forming is the least likely to change from the technique the potter learned during his/her apprenticeship (Wallaert 2008:179). Clay paste recipes are also conservative, but when potters move to a new area they commonly adjust their customary clay paste recipe as they adjust to the properties of new clays, available tempering materials, and/or new cultural norms in recipient communities (Gosselain 2008:176; Gosselain and Livingstone Smith 2005:42). Finishing treatments including decoration are the most readily changed by potters, e.g., from desire to innovate or in response to changes in consumer demand (Gosselain 2008, Wallaert 2008:196). Firing, like clay paste recipes, are intermediate in technical malleability and, hence, potential to change in response to environmental and social changes (Gosselain 2000). Thus, those steps in the chaînes opératoires that are the most critical to successfully complete the production of viable vessels appear to have more resistance to change over time or borrowing in comparison with the more visible, situational, and malleable steps such as decoration (Gosselain 2000).

There is a small amount of available information on fabric variation in i\&i pottery from Thai sites. Janet Douglas and Chureekamol Eyre (personal communication 2010) have done a pilot study of sixteen thin sections of i\&i sherds recovered from nine sites in the BMC/KSTUT ceramic subregion (Ban Mai Chaimongkol area on the Khok Samrong-Takli Undulating Terrain) in the eastern middle Chao Phraya Basin (see White and Eyre 2011 for further definition of ceramic subregions). Mineral tempers including granite and other igneous and metamorphic rock were found in thirteen sections. Grog plus rock was found in three, and none had organic inclusions.

This emphasis on mineral fabrics in one part of central Thailand contrasts with what so far has been found in other areas. At Khok Phanom Di near the Gulf of Thailand, Vincent (2004) reports that the burnished i\&i wares are predominantly tempered with orthodox grog. At Ban Chiang, grog and usually rice husks appear to be part of the clay paste recipes for i\&i and contemporaneous vessels, according to preliminary work done at the University of Pennsylvania (unpublished data from ceramic analysis 2010-2012; McGovern et al. 1985).

There is a small amount of information on forming, the manufacturing stage that could be the most informative of prehistoric potting community networks. Vincent (2004) reports probable slab construction for Khok Phanom Di i\&i vessels, whereas for Ban Chiang i\&i pots, thin coils are prominent with molded or simple basal slabs (unpublished records from ceramic analysis 2010-2012; Glanzman and Fleming 1985; White et al. 1991).

If we look at the decorated fields (with incising and impressing) themselves, we again find considerable technical variation. At Ban Chiang, the impressing was almost always done with rocker stamping, although with different implements. Most common is dentate rocker stamping (Figure 2b), but there are also some plain rocker stamping (Figure 2a), and one impression type the project is calling dapple (Figure 2c). From another study site, Don Klang, a different technique for applying the i\&i design concept is found; dentate designs are made with parallel comb impressions, and individual punctations are also present (Figure 2d). Note that Rispoli (1997) has commented on the absence of rocker stamping in the i\&i ceramics she has examined from central Thailand, and she noted the use of shell and other implements to make impressions. The key summary point is that there is clear technical variation between and within subregions in how the impressing was applied, even though a broadly-related design grammar can be recognized that spans many subregions. 

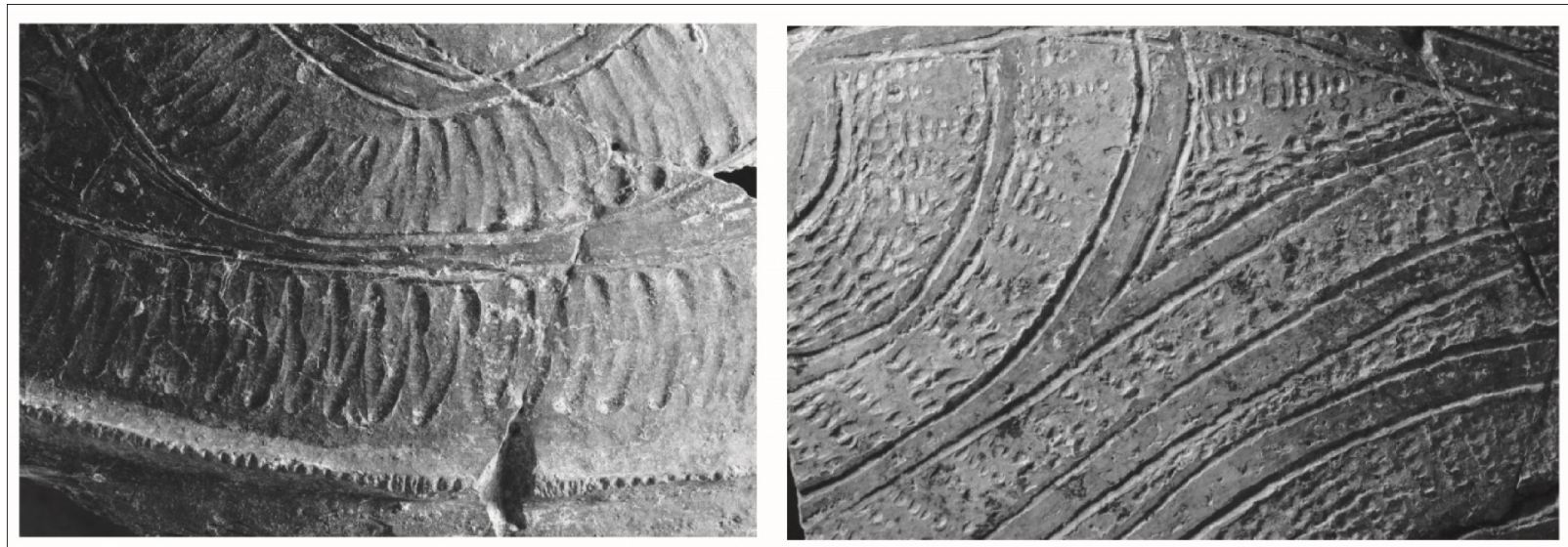

a.

b.
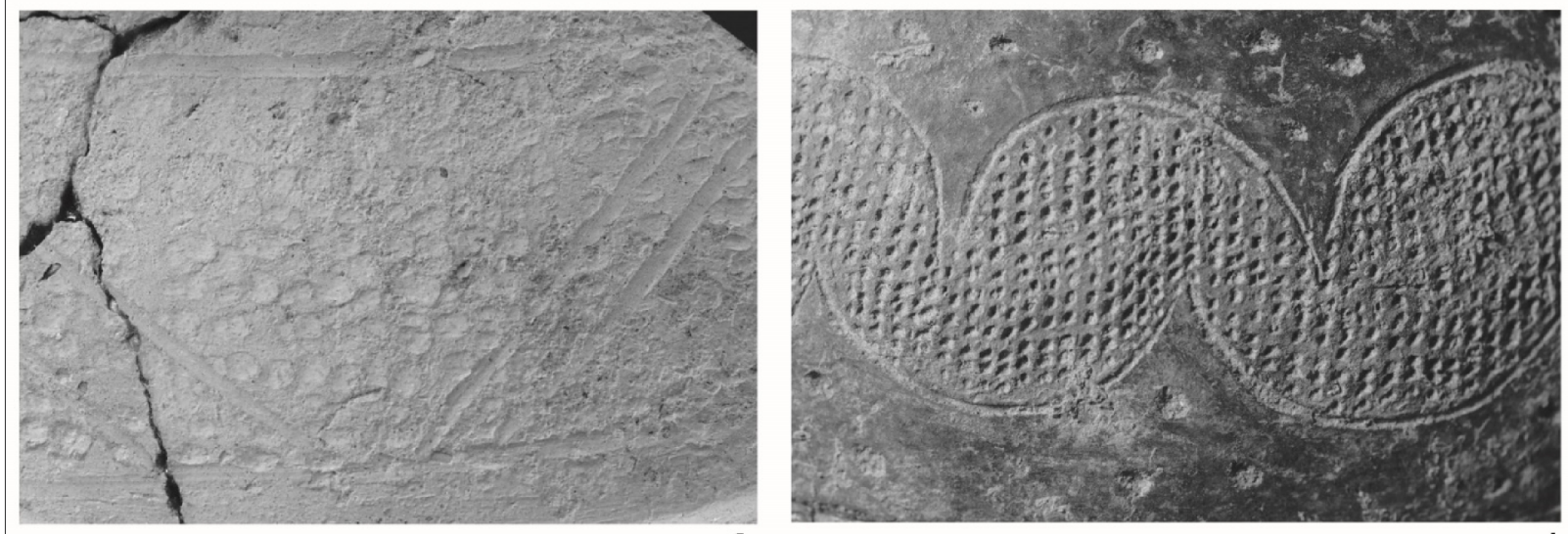

C.

Figure 2. Close-ups showing variation of $i \& i$ decoration from Ban Chiang (a, b, c) and Don Klang (d). Examples from Ban Chiang demonstrate rocker stamping with different implements to produce plain (a), dentate (b) and dappled (c) impressions. Don Klang example (d) has comb impressions.

This initial evidence for regional variability in the chaînes opératoires for i\&i pots suggests that, although i\&i pottery has a related decorative concept and similar grammar over a wide region, many distinct potting traditions, and presumably potting "communities of practice" (Sassaman and Rudolphi 2001; see also Thomas 2009), employed this decorative grammar and applied it technically in their own way.

The variability in fabric, forming, and surface treatment in i\&i pottery in Thailand contrasts clearly with Petrequin and Petrequin's (1999, cited in Spriggs 2011) argument for considerable uniformity in the Lapita pottery technology, which allowed them to argue for migrating Lapita potters, as noted above. Unlike the Lapita scenario of internal technical consistency, the technical and morphological variability so far documented in the i\&i pottery in Thailand does not lend itself to an argument that potters are rapidly migrating and bringing a uniform ceramic technological tradition along with them.

In addition, the observable technological variability also appears inconsistent with a few workshops producing vessels that are widely exchanged (cf., the Tumleo of the Sepik coast, Welsch and Terrell 1998:172), or with the idea that the same, limited number of people moved around in an itinerant craftsperson production model. Instead the Thai evidence currently available is consistent with different potters with different skills, knowledge, and technical traditions producing variant i\&i decoration on locally idiosyncratic forms made with locally distinct chaînes opératoires. The variability documented on an admittedly limited sample is most compatible with an interpretation that a decorative grammar is being borrowed by local potting communities which have their own potting traditions, similar to Gosselain's (2008:172) experience of Zarmaganda potters imitating Bella decoration, through observation and not apprenticeship. The borrowing of the decoration in this latter case would likely be consumer driven analogous to the situation where the Bella decoration was considered desirable (pretty) among consumers in the regional context of the Niger River, and so the Zarmaganda copied it.

In summary, the small amount of existing data on i\&i pottery in Thailand can provide the basis for several hypotheses about potting communities, social networks, and social mobility directly pertinent to testing several archaeological assumptions in the farming/language dispersal hypothesis. If thorough studies of pottery chaînes opératoires 


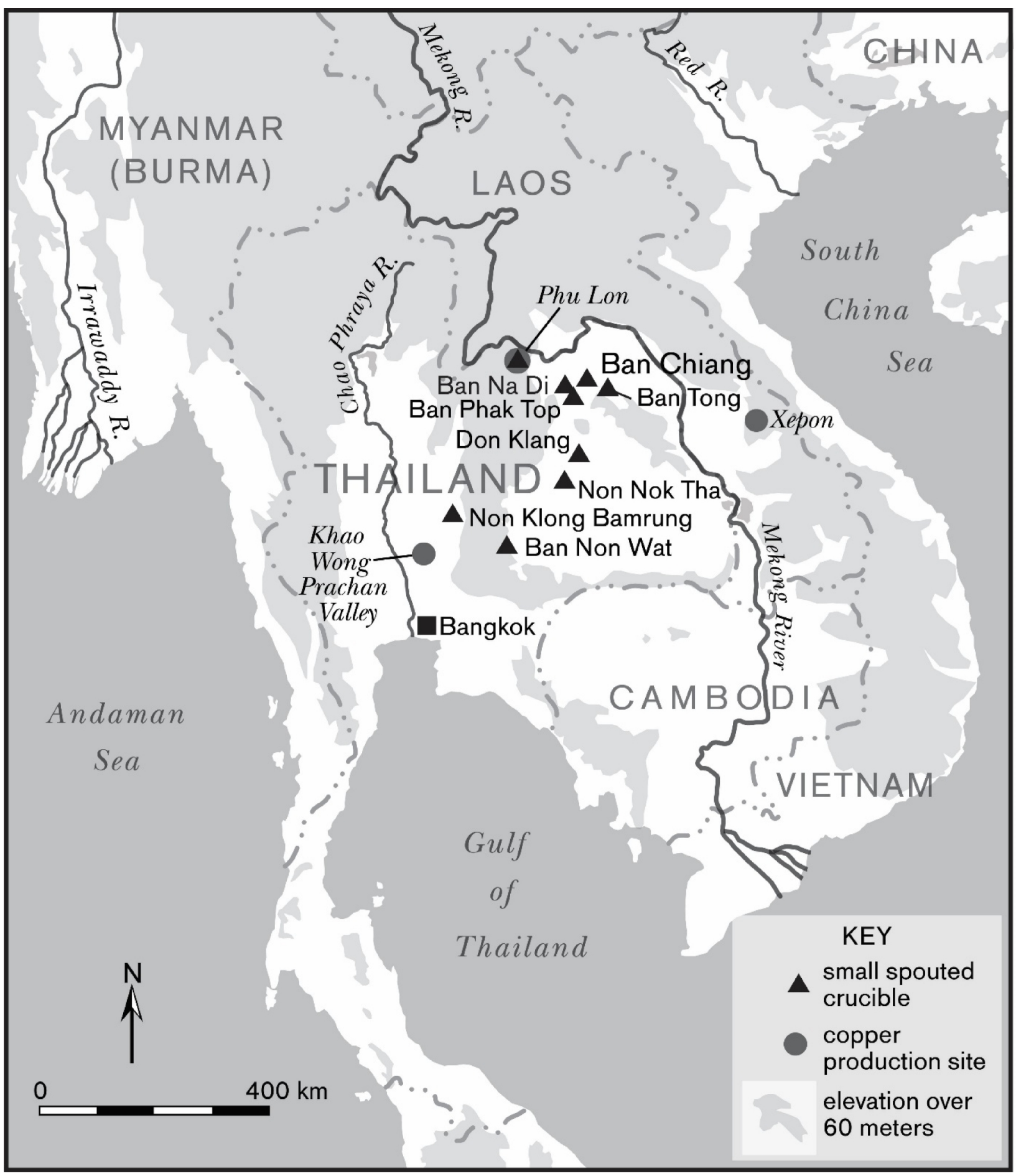

Figure 3. Map showing locations of three known copper production areas and the wide regional distribution of the common Southeast Asian spouted crucible.

of larger samples fail to show that potters moved in concert with a rapid progressive movement of farmers in this time period, the demographic claims tied to the spread of this pottery style for the farming/language dispersal (Higham 2002; Higham et al. 2011) should be re-examined and other hypotheses tested that could account for potters from different traditions borrowing a decorative grammar over a large region. 


\section{Bronze artifact manufacture}

It is fascinating that applying the same approach to the metallurgical evidence suggests very different social networks at play in bronze product manufacturing systems in comparison with the pottery production systems. The chaînes opératoires of bronze product manufacture show a remarkably consistent range of variability across large regions transcending the subregional variability in the ceramic traditions (White and Hamilton 2009). The widespread distribution of the small, spouted crucible type cross-cuts several ceramic subregions in northeast Thailand and has also been observed in at least one site in in central Thailand (Natapintu 1988:122; White and Hamilton 2009) (Figure 3 ). The consistently narrow repertoire of metal product classes and manufacturing equipment and procedures is testimony to a geographically broad community of skilled practitioners, at least for manufacturing final metal products in northeast and parts of central Thailand (White and Hamilton 2009; White and Pigott 1996). Although some production of copper objects was undertaken in some areas (Pigott and Natapintu 1988), tin bronze was the prevalent alloy at least in later prehistoric Thailand (White and Pigott 1996).

Where might we go with a regional understanding, taking into consideration the distinctive social networks suggested in the pottery and metal data? Top-down, centralized political economy models do not easily fit the data. White and Pigott (1996) argued that the overall evidence for copper production and copper-based product manufacturing was consistent with a community specialization economic model (as discussed in Costin 1991). Recent interpretation of Sepon production organization evidence in Laos also found evidence for "small family or tribal enterprises" as well as connections to regional trading networks, leaving open the question of a possible role for external control and the nature of some relationship at a later point with China (Tucci et al. 2014:12). Within Thailand, certainly the wide distribution of the common Southeast Asian crucible in villages away from ore sources in many ceramic subregions (cf. Figure 3 and Figure 1) demonstrates that metal artifact manufacturing was not centralized and that a segmented production system is in evidence there (White and Hamilton 2009; White and Pigott 1996). Lead isotope analytic data (e.g. Pryce et al. 2011, 2014) are adding evidence for the specific networks between individual locales producing copper and villages consuming copper-based products. These data lend further support for distinctions between the production and distribution networks for metals and ceramics, the former extending over hundreds of kilometers, the latter much more localized in extent.

\section{WHERE IS THIS LEADING?}

In my view, focus on production, consumption, technological relationships, and the social networks that underlay regional development will provide meaty contributions to understanding the prehistoric past of Southeast Asia. Implementing this approach should not be limited to studies of crafts but the perspective can be insightful in examining all societal processes (see White 2011 as an example addressing community perspectives on subsistence diversity in the late Pleistocene and early Holocene). An excellent metal age model from another region that echoes many of the features we find in metal age Thailand has been described by Shennan (1999) for the European alpine regional bronze age. His articulation of a regional system of interacting specialized communities fostering economic growth without top-down controls suggests the direction that appears to me most likely to bear fruit for interpreting the metal age economy of Thailand. (See White and Hamilton in press for extended discussion.)

\section{CONCLUDING THOUGHTS}

To summarize, I urge Southeast Asian archaeologists to focus on a front-view, emergent paradigm, on defining communities and networks in our data, and on applying the wide variety of archaeological methods and theories that have developed over the last thirty-some years to our data. These frameworks will enable us to make our own distinctive contributions to addressing questions on how prehistoric societies worked, how and why the workings of particular societies changed over time and space, who was interacting with whom, how they were interacting, and what it all means for understanding the regional longue durée. An authentic assessment of our data will bring them forward to the global archaeological spotlight in ways that the region's current dominant paradigm never will. This baton passes to the younger generation: there are so many new ideas out there to test, so many big arrows, so many methods, so many new models. If the younger generation of Southeast Asian archaeologists uses these riches wisely, they will take Southeast Asian archaeology far and fruitfully engage in the larger archaeological discussions of the $21^{\text {st }}$ century.

\section{ACKNOWLEDGMENTS}

I thank Helen Lewis for inviting me to give the original keynote address to the EurASEAA conference in Dublin, Marie-Claude Boileau for her research and insights into Ban Chiang pottery and technological system, Elizabeth Hamilton for her research and insights into Ban Chiang metallurgy, Kelsey Halliday Johnson for the close-up photographs of pottery in Figure 2, and Ardeth Anderson who prepared the maps and figures. Thanks also to Elizabeth Hamilton, Vincent Pigott, Marie-Claude Boileau, Cyler Conrad, Helen Lewis, and the anonymous peer reviewers for reading and commenting on earlier drafts of the text. Thanks to T. O. Pryce for suggesting submission of the text to the Journal of Indo-Pacific Archaeology.

\section{REFERENCES}

Acabado, S. 2014. Defining Ifugao social organization: "house," field, and self-organizing principles in the northern Philippines. Asian Perspectives (2013) 52(2):161-89.

Adams, R.L. and S.M. King, (eds.) 2011. Residential Burial: A Multiregional Exploration. Archeological Papers of the American Anthropological Association (20). Malden, MA: Wiley. 
Barrett, J.C. 2012. Agency: a revisionist account. In Ian Hodder (ed.) Archaeological Theory Today, second edition. Malden MA: Polity Press, pp. 146-166.

Bellwood, Peter, 2011. The Checkered Prehistory of Rice Movement Southwards as a Domesticated Cereal from the Yangzi to the Equator. Rice 4:93-103. DOI 10.1007/s12284-011-9068-9.

Bellwood, P., M. Oxenham, B.C. Hoang, N.K. Dzung, A. Willis, C. Sarjeant, P. Piper, H. Matsumura, K. Tanaka, N. Beavan-Athfield, T. Higham, N.Q. Manh and D.N. Kinh. 2013. An Son and the neolithic of southern Vietnam. Asian Perspectives (2011) 50(1-2):144-75.

Bird, D.W. and O'Connell, J.F. 2012. Human behavioral ecology. In Ian Hodder (ed.) Archaeological Theory Today, second edition. Malden MA: Polity Press, pp. 37-61.

Bleed, P. 1997. Content as variability, result as selection: Toward a behavioral definition of technology. In C.M. Barton and G.A. Clark (eds.) Rediscovering Darwin: Evolutionary Theory and Archaeological Explanation. Archaeological Papers of the American Anthropological Society no 7. Arlington: American Anthropological Association, pp. 95104.

Blench, R. 2011. The role of agriculture in the evolution of mainland Southeast Asia language phyla. In N.J. Enfield (ed.) Dynamics of Human Diversity: The Case of Mainland Southeast Asia. Canberra: Pacific Linguistics, pp. 125-52.

Bourdieu, P. 1977. Outline of a Theory of Practice. Cambridge: Cambridge University Press.

Carter, A.K., and L. Dussubieux. 2016. Geologic provenience analysis of agate and carnelian beads using laser ablationinductively coupled plasma-mass spectrometry (LA-ICPMS): a case study from iron age Cambodia and Thailand. Journal of Archaeological Science: Reports 6:321-31.

Costin, L.C. 1991. Craft specialization: issues in defining, documenting, and explaining the organization of production. In M.B. Schiffer (ed.) Archaeological Method and Theory, vol. 3. Tucson: University of Arizona Press, pp. 1-56.

Donegan, P. J., and D. Stamp. 2004. Rhythm and the synthetic drift of Munda. In Rajendra Singh (ed.) The Yearbook of South Asian Languages and Linguistics 2004. New Delhi; Thousand Oaks, Sage Publications, pp. 3-36.

Donohue, Mark, and Tim Denham. 2010. Farming and language in island Southeast Asia: Reframing Austronesian History. Current Anthropology 51(2):223-256.

Duke, B., N.J. Chang, I. Moffat, and W. Morris. 2016. The invisible moats of the Mun River Valley, northeast Thailand: the examination of water management devices at mounded sites through ground penetrating radar (GPR). Journal of Indo-Pacific Archaeology 40:1-11.

Enfield, N.J. (ed.). 2011. Dynamics of Human Diversity: The Case of Mainland Southeast Asia. Canberra: Pacific Linguistics.

Favereau, A., and B. Bellina. 2016. Thai-Malay Peninsula and South China Sea networks (500 BC-AD 200), based on a reappraisal of "Sa Huynh-Kalanay"-related ceramics. Quaternary International 416:219-27.

Fix, A. 2011. Origin of genetic diversity among Malaysian Orang Asli: An alternative to the demic diffusion model. In N.J. Enfield (ed.), Dynamics of Human Diversity. Canberra, Australia: Pacific Linguistics, pp. 277-291.
Fowler, Chris. 2013. The Emergent Past: A Relational Realist Archaeology of Early Bronze Age Mortuary Practices. Oxford: Oxford University Press.

Glanzman W. D. and Fleming S. J. 1985. Ceramic technology at prehistoric Ban Chiang, Thailand: fabrication methods. MASCA Journal 3(4): 114-21.

Gosselain, O.P. 1998. Social and technical identity in a clay crystal ball. In M. Stark (ed.) The Archaeology of Social Boundaries. Washington: Smithsonian Institution Press, pp. 78106.

Gosselain, O.P. 2000. Materializing identities: an African perspective. Journal of Archaeological Method and Theory 7(3): 187-217.

Gosselain, O.P. 2008. Mother Bella was not a Bella: inherited and transformed traditions in southwestern Niger. In M.T. Stark, B.J. Bowser, and L. Horne (eds.) Cultural Transmission and Material Culture. Tucson: University of Arizona Press, pp. 150-177.

Gosselain, O.P., and Alexandre Livingstone Smith. 2005. The source. clay selection and processing practices in Sub-Saharian Africa. In Alexandre Livingstone Smith, Dominique Bosquet and Rémy Martineau (eds.) Pottery Manufacturing Processes: Reconstruction and Interpretation. Oxford: Archaeopress, pp. 33-47.

Hanus, K. and D. Evans. 2015. Imaging the waters of Angkor: a method for semi-automated pond extraction from LiDAR data. Archaeological Prospection. Wiley Online Library, DOI: 10.1002/arp.1530

Higham, C. 1996. The Bronze Age of Southeast Asia. Cambridge: Cambridge University Press.

Higham, C. 2002. Languages and farming dispersals: Austroasiatic languages and rice cultivation. In P. Bellwood and C. Renfrew (eds.), Examining the Farming/language Dispersal Hypothesis. Cambridge UK: McDonald Institute for Archaeological Research, University of Cambridge, pp 223-232.

Higham, C.F.W. 2015. Social change during the bronze and iron ages of Northeast Thailand. In N.H. Tan (ed.), Advancing Southeast Asian Archaeology 2013: Selected Papers from the First SEAMEO SPAFA International Conference on Southeast Asian Archaeology. Bangkok, Thailand: SEAMEO SPAFA Regional Centre for Archaeology and Fine Arts, pp. 270-8.

Higham, C. F. W., Xie Guangmao, Lin Qiang. 2011. The prehistory of a Friction Zone: first farmers and hunters-gatherers in Southeast Asia. Antiquity 85:529-543.

Higham, C., and R. Thosarat 2012. Early Thailand: From Prehistory to Sukhothai. Bangkok: River Books.

Hodder, I. 2012. Introduction: contemporary theoretical debate in archaeology. In I. Hodder (ed.) Archaeological Theory Today, second edition. Malden MA: Polity Press, pp. 1-14.

Jones, A. 2002. Archaeological Theory and Scientific Practice: Topics in Contemporary Archaeology. Cambridge: Cambridge University Press.

King, C., N. Tayles, C. Higham, U. Strand-Vidarsdottir, R. A. Bentley, C. G. Macpherson, and G. Nowell. 2015. Using isotopic evidence to assess the impact of migration and the two-layer hypothesis in prehistoric northeast Thailand. American Journal of Physical Anthropology DOI: 10.1002/ajpa.22772. 
Kohler, T. 2012. Complex systems and archaeology. In I. Hodder (ed.) Archaeological Theory Today, second edition. Malden MA: Polity Press, pp. 93-123.

LaMotta, V. M. 2012. Behavioral archaeology. In I. Hodder (ed.) Archaeological Theory Today, second edition. Malden MA: Polity Press, pp. 62-92.

Lemonnier, Pierre.1986. The Study of Material Culture Today: Toward an Anthropology of Technical Systems. Journal of Anthropological Archaeology 5:147-186.

Lewis, H., J. White, and B. Bouasisengpaseuth. 2015. A buried jar site and its destruction: Tham An Mah Cave, Luang Prabang Province, Lao PDR. In N.H. Tan (ed.), Advancing Southeast Asian Archaeology 2013: Selected Papers from the First SEAMEO SPAFA International Conference on Southeast Asian Archaeology. Bangkok, Thailand: SEAMEO SPAFA Regional Centre for Archaeology and Fine Arts, pp. 72-82.

Liebmann, M. 2008. Postcolonial cultural affiliation: essentialism, hybridity, and NAGPRA In M. Liebmann, and U. Rizvi (ed.) Archaeology and the Postcolonial Critique. New York: Altamira Press pp. 73-90.

MacDonald, W. K. 1980a. The Bang Site, Thailand: an Alternative analysis. Asian Perspectives 21(1):30-51.

MacDonald, W. K. 1980b. Some Implications of Societal Complexity: Organizational Variability at Non Nok Tha, Thailand (2000-0 B.C.). Ph.D. dissertation, Department of Anthropology, University of Michigan. Ann Arbor, MI: University Microfilms International.

MacEachern, S. 1998. Scale, style, and cultural variation: technological traditions in the northern Mandara Mountains. In M. Stark (ed.) The Archaeology of Social Boundaries. Washington: Smithsonian Institution Press, pp. 107-131.

Marwick, B. 2008. Human behavioural ecology and stone artefacts in northwest Thailand during the terminal Pleistocene and Holocene. In J.-P. Pautreau, A.-S. Coupey, V. Zeitoun and E. Rambault (eds.), From Homo erectus to the Living Traditions. Chiang Mai: European Association of Southeast Asian Archaeologists, pp. 73-80.

McGovern, P.E., Vernon, W.W. and White, J.C. 1985. Ceramic technology at prehistoric Ban Chiang, Thailand: physiochemical analyses. MASCA Journal 3(4): 104-13.

Natapintu, S. 1988. Current research on ancient copper-base metallurgy in Thailand. In P. Charoenwongsa and B. Bronson (eds.) Prehistoric Studies: The Stone and Metal Ages in Thailand. Papers in Thai Antiquity, Vol. 1, Bangkok: Thai Antiquity Working Group, pp. 107-124.

Nguyeb Khac Su, Pham Minh Huyen, and Tong Trung Tin. 2004. Northern Vietnam from the Neolithic to the Han Period. In I. Glover and P. Bellwood (eds.) Southeast Asia, From Prehistory to History. New York:_RoutledgeCurzon, pp. 177208

Pigott, V.C. and S. Natapintu. 1988. Archaeological investigations into prehistoric copper production: the Thailand Archaeometallurgy Project 1984-1986. In R. Maddin. (ed.) The Beginning of the Use of Metals and Alloys. Papers from the Second International Conference on the Beginning of the Use of Metals and Alloys, Zhengzhou, China, 21-26 October 1986. Cambridge: MIT Press, pp. 156-62.

Pryce, T.O., M. Brauns., N. Chang, E. Pernicka, A.M. Pollard, C. Ramsey, T. Rehren, V. Souksavatdy, and T. Sayavongkhamdy. 2011. Isotopic and technological variation in prehistoric Southeast Asian primary copper production. Journal of Archaeological Science 38 (12): 3309-3322.

Pryce, T. O., S. Baron, B. H. M. Bellina, P. S. Bellwood, N. Chang, P. Chattopadhyay, E. Dizon, I. C. Glover, E. Hamilton, C. F. W. Higham, A. A. Kyaw, V. Laychour,S. Natapintu, Nguyen Viet, J. Pautreau, E. Pernicka, V.C. Pigott, M. Pollard, C. Pottier, A. Reinecke, T. Sayavongkhamdy, V. Souksavatdy, J. White. 2014. More questions than answers: the Southeast Asian Lead Isotope Project 20092012. Journal of Archaeological Science 42: 273-94.

Rispoli, F. 1997. Late third-mid second millennium BC pottery traditions in central Thailand: some preliminary observations in a wider perspective. In R. Ciarla and F. Rispoli, (eds.) South-east Asian Archaeology 1992. Proceedings of the Fourth International Conference of the European Association of South-east Asian Archaeologists. Rome, 28th September - 4th October 1992. Rome: Istituto Italiano per L'Africa e L'Oriente, pp. 59-97.

Rispoli, F. 2007. The incised \& impressed pottery style of mainland Southeast Asia: following the paths of Neolithization. East and West 57(1-4):235-304.

Sassaman, Kenneth E., and Wictoria Rudolphi. 2001. Communities of practice in the early pottery traditions of the American Southeast. Journal of Anthropological Research 57(4):407-425.

Schiffer, M. 2001. Toward an Anthropology of Technology. In M. Schiffer (ed.) Anthropological Perspectives on Technology. Albuquerque: University of New Mexico Press, pp. $1-15$.

Shennan, S. 1999. Cost, benefit and value in the organization of early European copper production. Antiquity 73: 352-63.

Shennan 2012 Darwinian cultural evolution. In I. Hodder (ed.) Archaeological Theory Today, second edition. Malden MA: Polity Press, pp. 15-36.

Sidwell, P. and R. Blench. 2011. The Austroasiatic Urheimat: the southeastern riverine hypothesis. In N.J. Enfield (ed.) $D y$ namics of Human Diversity: The Case of Mainland Southeast Asia. Canberra: Pacific Linguistics, pp. 315-43.

Spriggs, M. 2011. Archaeology and the Austronesian expansion: where are we now? Antiquity 85 (328): 510-28.

Thomas, Tim. 2009. Communities of practice in the archaeology of New Georgia, Rendova and Tetepar. In P. J. Sheppard and T. Thomas, and G. Summerhayes (eds.) Lapita: Ancestors and Descendants. Aukland: New Zealand Archaeological Association, pp. 119-145.

Thornton, C.P. and B.W. Roberts. 2014. Introduction. In B.W. Roberts and C.P. Thornton (eds.), Archaeometallurgy in Global Perspective: Methods and Syntheses. New York: Springer, pp. 1-9.

Tucci A., Thongsa Sayavongkhamdy, N. Chang, and Viengkeo Souksavatdy 2014. Ancient copper mining in Laos: heterachies, incipient states or post-state anarchists? Journal of Anthropology and Archaeology 2(2): 1-15.

Vincent, B.A. 2004. The Excavation of Khok Phanom Di, a Prehistoric Site in Central Thailand. Volume VI: The Pottery. The Material Culture Part II. Reports of the Research Committee Vol. 70. London: Society of Antiquaries of London.

Wallaert, Héllène. 2008. The Way of the potter's mother: apprenticeship strategies among the Dii potters from Cameroon, West Africa. In M.T. Stark, B.J. Bowser, and L. Horne 
(eds.) Cultural Transmission and Material Culture.. Tucson: University of Arizona Press, pp. 178-198.

Weber, S., H. Lehman, T. Barela, S. Hawks, and D. Harriman. 2010. Rice or millets: early farming strategies in prehistoric central Thailand. Archaeological and Anthropological Sciences 2: 79-88.

Welsch, R. L. and J. E. Terrell. 1998. Material culture, social fields, and social boundaries on the Sepik Coast of New Guinea. In M. T. Stark (ed.) The Archaeology of Social Boundaries. Washington, D.C.: Smithsonian Series in Archaeological Inquiry, Smithsonian Institution Press, pp. $50-77$.

White J. C. 2002. Series editor's preface. In Ban Chiang, a Prehistoric Village Site in Northeast Thailand I: the Human Skeletal Remains (by.M. Pietrusewsky and M. T. Douglas). Philadelphia: Thai Archaeology Monograph Series, 1; University Museum Monograph 111, University of Pennsylvania Museum of Archaeology and Anthropology, pp. xvixvii.

White, J.C. 2011. Emergence of cultural diversity in mainland Southeast Asia: a view from prehistory. In N.J. Enfield (ed.), Dynamics of Human Diversity: The Case of Mainland Southeast Asia., Canberra:Pacific Linguistics, pp. 946.

White, J.C., and C.O.Eyre. 2011. Residential burial and the metal age of Thailand. In R.L. Adams and S.M. King (eds.) Residential Burial: A Multiregional Exploration. Archaeological Papers of the American Anthropological Association No. 20. Malden, MA: Wiley, pp. 59-78.

White, J.C. and Hamilton, E.G. 2009. The transmission of early bronze technology to Thailand: new perspectives. Journal of World Prehistory 22 (4): 357-97.

White, J.C. and Hamilton, E.G. in press. Ban Chiang, a Prehistoric Village Site in Northeast Thailand II: The Metal Remains in Regional Context. Philadelphia: University of Pennsylvania Museum.

White, J.C., and V.C. Pigott. 1996. From community craft to regional specialization: intensification of copper production in prestate Thailand. In B. Wailes (ed.) Craft Specialization and Social Evolution: In Memory of V. Gordon Childe. University Museum Monograph 93, University Museum Symposium Series Vol. 6. Philadelphia: University of Pennsylvania Museum of Archaeology and Anthropology, pp. 151-75.

White J. C., W. W. Vernon, S. J. Fleming, W. D. Glanzman, R. G. V. Hancock, and A. Pelcin. 1991. Preliminary cultural implications from initial studies of the ceramic technology at Ban Chiang. Bulletin of the Indo-Pacific Prehistory Association 11: 188-203. 